\title{
Therapeutic effect of amino acid mixture on type 1 diabetes mellitus with impaired renal methionine reabsorption
}

\author{
Chiung-Chi Peng ${ }^{1}$, Yaw-Bee Ker ${ }^{2}$, Chiu-Lan Hsieh ${ }^{3}$, Chien-Ning Huang ${ }^{4,5}$, Kuan-Chou Chen ${ }^{6,7^{*}}$ and Robert Y. Peng ${ }^{8}$ \\ *Correspondence: kc.chen416@msa.hinet.net

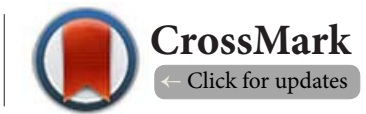 \\ ${ }^{1}$ Graduate Institute of Clinical Medicine, College of Medicine, Taipei Medical University, 250 Wu-Xing St., 110, Taipei, Taiwan. \\ ${ }^{2}$ Department of Applied Food Technology, Hungkuang University, 34 Chung-Chie Rd., Shalu District, Taichung City, 43302, Taiwan. \\ ${ }^{3}$ Graduate Institute of Biotechnology, Changhua University of Education, 1 Jin-De Rd., Changhua, Taiwan. \\ ${ }^{4}$ Department of Internal Medicine, Chung-Shan Medical University, 110 Sec.-1, Chien-Kuo North Road, Nan-Toon District, Taichung City \\ 402, Taiwan. \\ ${ }^{5}$ Division of Endocrinology and Metabolism, Chung-Shan Medical University Hospital, 110 Sec.-1, Chien-Kuo North Road, Nan-Toon \\ District, Taichung City 402, Taiwan. \\ ${ }^{6}$ Department of Urology, Shuang Ho Hospital, Taipei Medical University, 250, Wu-Xin St., Xin-Yi District, 110, Taipei, Taiwan. \\ ${ }^{7}$ Department of Urology, School of Medicine, College of Medicine, Taipei Medical University, 250, Wu-Xin St., Xin-Yi District, 110, Taipei, \\ Taiwan. \\ ${ }^{8}$ Research Institute of Biotechnology, Hungkuang University, 34 Chung-Chie Rd., Shalu District, Taichung City, 43302, Taiwan.
}

\begin{abstract}
Background: The main manifestation of Type 1 diabetes mellitus (T1DM) is insulin insufficiency which eventually leads to body weight loss and a diversity of organ dysfunctions. On the other hand, quercetin (QT) is an antioxidant and an insulin secretagogue. We hypothesize that the amino acid mixture (AAM) preparation and/or AAM+ quercetin(QT) probably could ameliorate these adverse effects.

Methods: The STZ-DM-Sprague Dawley rat model was carried out and respectively treated with QT, AAM, and AAM+QT. The relevant physiological and biochemical changes in serum and urinary parameters were examined.

Results: T1DM exhibited severe insulin insufficiency, body weight loss, increased kidney/body weight ratio, BUN, creatinine clearance, albuminuria and proteinuria, declined serum albumin and amino acid reabsorption involving methionine, leucine and isoleucine. The control showed severe serinuria $(12.0 \pm 0.2 \mathrm{mg} / \mathrm{mL})(p<0.001)$. AAM caused valinuria $(3.6 \pm 0.2 \mathrm{mg} / \mathrm{mL})$, argininuria $(6.9 \pm 0.2 \mathrm{mg} / \mathrm{mL})$ and histidinuria $(6.5 \pm 0.1 \mathrm{mg} / \mathrm{mL})(p<0.05)$. T1DM rats revealed hyperglycinuria $(21.4 \pm 0.2 \mathrm{mg} / \mathrm{mL})(p<0.01)$; AAM alleviated hyperglycinuria $(13.7 \pm 0.2 \mathrm{mg} / \mathrm{mL})(p<0.001)$ but evoked isoleucinuria $(8.2 \pm 0.2 \mathrm{mg} / \mathrm{mL})(p<0.05)$; QT elicited methioninuria $(23.1 \pm 0.3 \mathrm{mg} / \mathrm{mL})$ in T1DM and the control $(p<0.001)$; AAM+QT alleviated the methioninuria with extra leucinuria $(11.3 \pm 0.4 \mathrm{mg} / \mathrm{mL})(p<0.05)$, isoleucinuria $(11.4 \pm 0.4 \mathrm{mg} / \mathrm{mL})$, tryptophanuria, argininuria and lysinuria $(p<0.05)$.

Conclusion: T1DM exhibits severe insulin insufficiency, resulting in severe body weight loss and increased kidney/body weight ratio. T1DM and QT tend to induce methioninineuria. AAM+QT can rescue methioninuria at the expense of leucinuria, isoleucinuria, tryptophanuria, argininuria and lysinuria, implicating the use of AAM with extra supplement of insulin, leucine, isoleucine, tryptophan, arginine and lysine is feasible for alleviation of T1DM.
\end{abstract}

Keywords: Type 1DM, methioninuria, serinuria, leucinuria, amino acid therapy

\section{Introduction}

Diabetes mellitus (DM) is a progressive metabolic disorder affecting millions worldwide $[\mathbf{1}, \mathbf{2}]$. The SEARCH for Diabetes in Youth Study (www.searchfordiabetes.org/) has provided the first national data on prevalence of diabetes in youth: 1 of every 523 youth had physician diagnosed diabetes in 2001, including both type 1 (T1DM) and type 2 diabetes (T2DM), and about 15,000 youth are diagnosed with T1DM each year [3].

T1DM is a gene-linked disease that is characterized with insulin insufficiency, hyperglycemia, glucosuria and weight loss [4]. Scientists have identified nearly 50 genes or gene regions associated with T1DM. Scientists have identified a key gene region that contributes nearly half the increased risk of developing type 1 diabetes [3]. Individuals with this disease require medications to control their blood glucose $[1,2]$.

Instead of burning the carbohydrates, triglycerides are broken down (lipolysis) and free fatty acids are beta-oxidized in liver of T1DM patients to compensate the insufficient energy, as consequence, leading to diabetic ketoacidosis. [5].

The complications with DM are divided into two groups, macrovascular and microvascular complications [6-8]. Microalbuminuria (urine albumin) occurs when the kidney 
Peng et al. Journal of Diabetes Research \& Clinical Metabolism 2014,

leaks small amounts of albumin into the urine, in other words, when there is an abnormally high permeability for albumin in the renal glomerulus [6-8]. As a rule, plasma levels of total protein and albumin in DM patients are significantly lower than those in non DM patients [9]. Apart from this, in the kidney more than $95 \%$ of amino acids are reabsorbed in the proximal tubule [10-12]. The etiologic cause of aminoaciduria may involve the genetic and the environmental factors [13]. In view of the amino acid specificity, a diversity of inherited disordered amino acid reabsorption has been demonstrated, such as Hartnup disorder, cystinuria [14,15], argininuria [16], iminoglycinuria, dicarboxylic aminoaciduria $[13,17]$, and lysinuric protein intolerance [10]. More relevantly, the alterations in plasma branched-chain amino acids (valine, isoleucine and leucine) and alanine have been described in patients with T1DM who had poor metabolic control [18]. On the other hand, quercetin (QT), a potent prooxidant as well as an antioxidant, exhibits rather potent insulin secretagogue bioactivity [19]. Considering that the supply of sufficient protein building stones could be beneficial to improve defected protein homeostasis as described by Nakamoto and Suzuki [9], we proposed that the amino acid mixture (AAM) preparation and/or AAM+ quercetin(QT) could be biochemically effective to ameliorate the severely lowered plasma levels of total protein and albumin in T1DM patients. The STZ-DM- Sprague Dawley rat model was carried out and treated with AAM alone and AAM plus QT treatments. The relevant physiological and biochemical changes in serum and urinary parameters were examined.

\section{Methods}

\section{Chemicals}

Streptozotocin (STZ) was a product of Ausmausco Pharma Co., Ltd. (China). Assay max mouse Insulin (Insulin ELISA Kit) was supplied by AssayPro (USA). The Moriamin-SN Injection ${ }^{\circledR}$ for peripheral i.v. was supplied by China Chemical And Pharmaceutical Co. Ltd. (Taiwan) (refer to Supplementary Table S1). $\mathrm{N}$-(tert-butyldimethylsilyl)-N-methyl-trifluoroacetamide (also known as TBDMS-MTFA or MTBSTFA): the amino acid derivating agent was obtained from Merck KGaA (Darmstadt, Germany). Other chemicals not indicated were provided by Wako Pure Chemical Co. (Osaka, Japan).

\section{Animals}

This experiment was proved by the Institutional Animal Care and Ethic Committee of The Taipei Medical University (Taipei, Taiwan) and performed in accordance with the ethical standards and Animal Welfare Act laid down in the 1964 Declaration of Helsinki and its later amendments. Sixty four male Sprague-Dawley rats, age week 6, weighing 265-287 g were purchased from BioLasCo Animal Centre (Taipei, Taiwan). These rats were randomly housed in animal room conditioned at $24 \pm 2{ }^{\circ} \mathrm{C}, \mathrm{RH} 70-75 \%$, with a $12 \mathrm{~h} / 12 \mathrm{~h}$ light/night cycle, fed on basic chows and water ad libitum, and acclimated in the animal room for the first week.

\section{Treatment}

The rats were divided into eight groups, 8 in each: Group 1 was the normal control. Group 2, AAM ip treated control with Moriamin $1.6 \mathrm{~mL} /$ rat-day. Group 3, QT only ip treated control (70 mg/kg-day, suspended in PBS). Group 4, ip AAM+QT. Group 5, DM group. Group 6, DM treated with ip AAM. Group 7, DM treated with ip QT. Group 8, DM treated with ip AAM+QT. The animals were separated and caged, 2 rats in each cage. To induce DM model, STZ at 65 mg/kg was ip applied at week 2 . The DM induction period took 2 weeks (from week 2 to week 4). The blood sugar levels of rats were taken at week 4 and at week 9 . The body weight was taken every week. The QT and AMM therapy started at the end of week 4 until week 9. In the whole duration of experiment, the rats were not allowed to access any extra outside-cage exercise.

\section{Urine collection and analysis}

Rats were moved to the metabolic cage two days before the end of week. The urine was collected from 8:00 am to 8:00 am of the following day. The total volume of urine excreted per day by each individual was taken. The urinary samples were analyzed fresh for urinary protein, urinary urea nitrogen, creatinine, or immediately stored in the freezer at $0-4^{\circ} \mathrm{C}$ when not in use. The urinary urea nitrogen $\left(\mathrm{N}_{\mathrm{UU}}\right)$ (the equivalent of BUN in blood), glucose, and creatinine were measured by reagents supplied by Siemens (Bakersfield, CA, USA) and the automatic analyzer (Type Ciba-Corning Express Plus was purchased from Ciba-Corning (USA). The urinary protein concentration was measured using ELISA reader.

\section{Blood collection and analysis}

The blood samples were withdrawn from the abdominal aorta under i.p ketamine and xylasine anesthesia. The sample blood was centrifuged at $3000 \mathrm{~g}$ to separate the serum, which was measured for parameters including insulin, glucose, albumin, $B U N$, and creatinine adopting reagents supplied by Siemens (Bakersfield, CA, USA) and the automatic analyzer manufactured by Ciba-Corning Express Plus) (Ciba-Corning, USA). After the final blood collection, the rats were euthanized by i.p ketamine and xylasine anesthesia.

\section{Estimated glomerular filtration rate (eGFR)}

The eGFR is typically recorded in units of volume per time, e.g. $\mathrm{mL} / \mathrm{min}$ as suggested by Stevens et al., [20]. The following formula were used to calculate the estimated glomerular filtration rate (eGFR):

$$
\mathrm{eGFR}=\left(\mathrm{C}_{\mathrm{ur}} \times \mathrm{F}_{\mathrm{ur}}\right) / \mathrm{C}_{\mathrm{pl}} \ldots \ldots . \mathrm{Eq} 1
$$

where $C_{u r}$ is the urine concentration $F_{u r}$ is the urine flow rate, $\mathrm{C}_{\mathrm{pl}}$ is the plasma concentration. For clinical use, e-GFR usually is expressed in creatinine clearance, $C_{C r}$. Briefly, $24 \mathrm{~h}$ urine was collected to determine the amount of creatinine that was removed from the blood over $24 \mathrm{~h}$ interval. The creatinine 
clearance $\left(\mathrm{C}_{\mathrm{c}^{\prime}} \mathrm{mL} / \mathrm{min}\right)$ is calculated from the creatinine concentration in the collected urine sample $\left(\mathrm{Cr}_{\mathrm{ur}} \mathrm{mg} / \mathrm{dL}\right)$, urine flow rate $(\mathrm{F}, \mathrm{mL} / \mathrm{min})$, and the plasma concentration $\left(\mathrm{Cr}_{\mathrm{pl}}, \mathrm{mg} /\right.$ $\mathrm{dL}$ ) (Eq. 2). Since the product of urine concentration and urine flow rate yields creatinine excretion rate, which is the rate of removal from the blood, creatinine clearance is calculated as removal rate per min $\left(\mathrm{Cr}_{\mathrm{ur}} \times \mathrm{v}\right)$ divided by the plasma creatinine concentration $\left(\mathrm{Cr}_{\mathrm{p}}\right)$. (National Kidney Foundation, 2002) [21], which mathematically is expressed as

$$
\mathrm{C}_{\mathrm{cr}}=\left(\mathrm{Cr}_{\mathrm{ur}} \times \mathrm{F}\right) / \mathrm{Cr}_{\mathrm{pl}}(\mathrm{mL} / \mathrm{min}) \ldots \ldots . . \mathrm{Eq} 2
$$

\section{Organ collection}

After euthanized, the kidneys were immediately excised, rinsed twice with PBS, and the adhering PBS was sucked off using the face-tissues. The kidney weights were taken.

\section{Amino acid analysis \\ Derivatization of amino acids}

Method of Deng et al., [22]. was adopted with slight modification to conduct the amino acid analysis. This method has the advantages to successfully detect glutamine and asparagine. Briefly, the urine samples were lyophilized. To each lyophilized residue, norleucine (to serve the internal reference standard) $0.4 \mathrm{mg}$ and $200 \mathrm{~mL}$ pyridine was added. The mixture was agitated to facilitate the dissolution. The reaction mixture was transferred into a $2 \mathrm{~mL}$ reaction vessel. The derivation of amino acids were conducted using the derivatization reagent ( $\mathrm{N}$-methyl-N-(tert-butyldimethylsilyl) -trifluoroacetamide (MTBSTFA) in pyridine. MTBSTFA $100 \mathrm{~mL}$ was added, agitated and well mixed. The reaction vessels were placed onto a derivation heating plate held at $100^{\circ} \mathrm{C}$ for $50 \mathrm{~min}$. The reaction vessels were agitated every $10 \mathrm{~min}$ while undergoing reactions. After the reaction was finished, the reaction mixture was transferred into sample vials. The volume of solution was reduced by the nitrogen blowing until a minimum soluble phase was achieved (note: avoid any crystallization to occur). The concentrated sample solution was subjected to GC-FID analysis. The authentic amino acid samples, each $0.3 \mathrm{mg}$, were similarly treated.

\section{GC/FID instrument and analysis}

The GC/MS chromatography (Angilent 6890, Wilmington, DE, USA) installed with an FID detector and a column HP-5MS (lxid $=30 \mathrm{~m} \times 0.25 \mathrm{~mm}$, film thickness $=0.25 \mu \mathrm{m}$ ) was used for GC/FID analysis. The flow rate of carrier gas nitrogen was operated at $0.8 \mathrm{~mL} / \mathrm{min}$. The temperature of the detector FID and the injection port was held at 305 and $300^{\circ} \mathrm{C}$, respectively. The elution temperature was programmed initially at $50^{\circ} \mathrm{C}$ for 1 $\mathrm{min}$, then at an elevation rate $10^{\circ} \mathrm{C} / \mathrm{min}$ up to $300^{\circ} \mathrm{C}$ and held at which for $6.5 \mathrm{~min}$. The reference retention times for each amino acid are listed in Table 1. The contents of glutamine (Gln) and asparagine (Asn) were calculated according to the following equations.

1. To calculate glutamine (Gln) content:
$W_{G I n}=\left(A_{G I n} / A_{\text {nol }}\right) \times 0.4 \times 7.4459$

Where $W_{G l n}$ is the total amount of glutamine under glutamine peak.

$A_{G l n}$ is the total area under glutamine peak.

$A_{\text {nol }}$ is the area under peak exhibited by the internal standard norleucine $(0.4 \mathrm{mg})$. And 7.4459 is the reaction coefficient of glutamine.

2. To calculate asparagine (Asn) content:

$W_{\text {Asn }}=\left(A_{\text {Asn }} / A_{\text {nol }}\right) \times 0.4 \times 4.3429$

Where $\mathrm{W}_{\mathrm{Asn}}$ is the total amount of asparagine under asparagine peak.

$A_{A s n}$ is the total area under asparagine peak

$A_{\text {nol }}$ is the area under peak exhibited by the internal standard norleucine $(0.4 \mathrm{mg})$. And 4.3429 is the reaction coefficient of asparagine.

\section{Statistical analysis}

Data were presented as mean \pm SEM and analyzed by one-way analysis of variance with Tukey multiple $t$-test to compare between treatment groups using GraphPad Prism v4 (GraphPad Software, La Jolla, CA, USA). The CL level $p<0.05$ was considered statistically significant for the indicated $\mathrm{n}$ per group.

\section{Results}

Obviously, the T1DM rats were suffering from severe body weight loss, insulin insufficiency (Table 1), hyperglycemia and glucosuria (Table 2). An apparent positive correlation between the body weight gain and the serum insulin levels was perceived in all groups (Table 1). The rats exhibited a body weight range $265-287 \mathrm{~g}$ and insulin levels within $1.4 \pm 0.5 \mu \mathrm{g} / \mathrm{mL}$ when initially caged. The insulin levels at week four were $1.4 \pm 0.4$, $1.3 \pm 0.4,1.4 \pm 0.2$, and $1.4 \pm 0.3 \mu \mathrm{g} / \mathrm{mL}$ respectively for the control, AAM, QT, and AAM+QT rats. Contrasting to the DM-associated rats, the serum insulin levels were significantly lowered to $0.7 \pm 0.3,0.8 \pm 0.2,0.7 \pm 0.4$, and $0.9 \pm 0.2 \mu \mathrm{g} / \mathrm{mL}$ in the $\mathrm{DM}$, $\mathrm{DM}+\mathrm{AAM}, \mathrm{DM}+\mathrm{QT}$, and DM+AAM+QT rats $(p<0.001)$ (Table 1$)$. Similar trend was found at week six and week nine (Table 1). At week four the difference in body weight gain between the DM-associated and the normal groups became $290 \pm 9$, $290 \pm 5 \mathrm{~g}$ vs. $324 \pm 8-326 \pm 7 \mathrm{~g}$ (Table 1). As seen, the body weight of the control groups increased steadily from $324-325 \mathrm{~g}$ at week four to $350 \pm 8 \mathrm{~g}-363 \pm 7 \mathrm{~g}$ at week nine. Worth note, the QT alone administered group showed significantly lowered body weight. While the body weights in the DM-associated rats were almost retarded all the way through the same period to $318 \pm 6 \mathrm{~g}, 292 \pm 5 \mathrm{~g}, 309 \pm 9 \mathrm{~g}$, and $292 \pm 6 \mathrm{~g}$ respectively in the $\mathrm{DM}, \mathrm{DM}+\mathrm{AAM}, \mathrm{DM}+\mathrm{QT}$, and $\mathrm{DM}+\mathrm{AAM}+\mathrm{QT}$ rats $(p<0.001)$ (Table 1). Similarly, the body weight gain in the DM+AAM+QT as well as the DM+AAM rats was severely retarded (Table 1 ). The urinary glucose was entirely undetected in all controls compared to that raised to $80 \pm 6,52 \pm 7,43 \pm 6$, and $45 \pm 5 \mu \mathrm{g} / \mathrm{L}$ in the $\mathrm{DM}, \mathrm{DM}+\mathrm{AAM}, \mathrm{DM}+\mathrm{QT}$, and $\mathrm{DM}+\mathrm{AAM}+\mathrm{QT}$ rats $(p<0.001)$ (Table 2). The blood glucose level of the normal, AA and QT controls were very comparably to maintain at $185 \pm 15 \mathrm{mg} /$ 
Peng et al. Journal of Diabetes Research \& Clinical Metabolism 2014,

http://www.hoajonline.com/journals/pdf/2050-0866-3-5.pdf

Table 1. Correlation of serum insulin levels with body weight variation ${ }^{\star}, \dagger$,

\begin{tabular}{|c|c|c|c|c|c|c|c|c|}
\hline \multirow{2}{*}{ Group } & \multicolumn{8}{|c|}{ week/body weight $(\mathrm{g}) /$ insulin level $(\mu \mathrm{g} / \mathrm{L})$} \\
\hline & 1 & 2 & 3 & 4 & 5 & 6 & 8 & 9 \\
\hline control & $\begin{array}{l}265-287 \\
1.4 \pm 0.5\end{array}$ & $\begin{array}{l}299 \pm 5 \\
--\end{array}$ & $\begin{array}{l}312 \pm 6 \\
--\end{array}$ & $\begin{array}{l}325 \pm 5 \\
1.4 \pm 0.4\end{array}$ & $\begin{array}{l}335 \pm 6 \\
--\end{array}$ & $\begin{array}{l}345 \pm 5 \\
1.4 \pm 0.5\end{array}$ & $\begin{array}{l}357 \pm 6 \\
--\end{array}$ & $\begin{array}{l}363 \pm 7 \\
1.4 \pm 0.5\end{array}$ \\
\hline AAM & $\begin{array}{l}265-287 \\
1.4 \pm 0.5\end{array}$ & $\begin{array}{l}300 \pm 5 \\
--\end{array}$ & $\begin{array}{l}313 \pm 6 \\
--\end{array}$ & $\begin{array}{l}326 \pm 7 \\
1.3 \pm 0.4\end{array}$ & $\begin{array}{l}336 \pm 5 \\
--\end{array}$ & $\begin{array}{l}347 \pm 7 \\
1.3 \pm 0.6\end{array}$ & $\begin{array}{l}355 \pm 6 \\
--\end{array}$ & $\begin{array}{l}362 \pm 6 \\
1.3 \pm 0.4\end{array}$ \\
\hline QT & $\begin{array}{l}265-287 \\
1.4 \pm 0.5\end{array}$ & $\begin{array}{l}298 \pm 7 \\
--\end{array}$ & $\begin{array}{l}316 \pm 6 \\
--\end{array}$ & $\begin{array}{l}324 \pm 8 \\
1.4 \pm 0.2\end{array}$ & $\begin{array}{l}332 \pm 8 \\
--\end{array}$ & $\begin{array}{l}344 \pm 8 \\
1.4 \pm 0.3\end{array}$ & $\begin{array}{l}357 \pm 7 \\
--\end{array}$ & $\begin{array}{l}362 \pm 8 \\
1.4 \pm 0.4\end{array}$ \\
\hline $\mathrm{AAM}+\mathrm{QT}$ & $\begin{array}{l}265-287 \\
1.4 \pm 0.5\end{array}$ & $\begin{array}{l}299 \pm 8 \\
--\end{array}$ & $\begin{array}{l}317 \pm 7 \\
--\end{array}$ & $\begin{array}{l}324 \pm 7 \\
1.4 \pm 0.3\end{array}$ & $\begin{array}{l}333 \pm 8 \\
--\end{array}$ & $\begin{array}{l}340 \pm 7 \\
1.4 \pm 0.3\end{array}$ & $\begin{array}{l}347 \pm 6 \\
--\end{array}$ & $\begin{array}{l}350 \pm 8^{\&} \\
1.4 \pm 0.3\end{array}$ \\
\hline $\mathrm{DM}$ & $\begin{array}{l}265-287 \\
1.4 \pm 0.5\end{array}$ & $\begin{array}{l}290 \pm 6^{8} \\
--\end{array}$ & $\begin{array}{l}300 \pm 6^{8} \\
--\end{array}$ & $\begin{array}{l}305 \pm 6^{8} \\
0.7 \pm 0.3^{8}\end{array}$ & $\begin{array}{l}310 \pm 8^{8} \\
--\end{array}$ & $\begin{array}{l}314 \pm 5^{8} \\
0.7 \pm 0.2^{8}\end{array}$ & $\begin{array}{l}316 \pm 7^{\&} \\
--\end{array}$ & $\begin{array}{l}318 \pm 6^{8} \\
0.7 \pm 0.3^{8}\end{array}$ \\
\hline $\mathrm{DM}+\mathrm{AAM}$ & $\begin{array}{l}265-287 \\
1.4 \pm 0.5\end{array}$ & $\begin{array}{l}288 \pm 7^{8} \\
--\end{array}$ & $\begin{array}{l}287 \pm 6^{8} \\
--\end{array}$ & $\begin{array}{l}290 \pm 5^{\text {\&ə }} \\
0.8 \pm 0.2^{8 \times}\end{array}$ & $\begin{array}{l}291 \pm 5^{8} \\
--\end{array}$ & $\begin{array}{l}291 \pm 6^{8 \partial} \\
0.7 \pm 0.3^{8 \times}\end{array}$ & $\begin{array}{l}291 \pm 7^{8} \\
--\end{array}$ & $\begin{array}{l}292 \pm 5^{8 \partial} \\
0.7 \pm 0.3^{8 x}\end{array}$ \\
\hline $\mathrm{DM}+\mathrm{QT}$ & $\begin{array}{l}265-287 \\
1.4 \pm 0.5\end{array}$ & $\begin{array}{l}287 \pm 7^{8} \\
--\end{array}$ & $\begin{array}{l}288 \pm 8^{8} \\
--\end{array}$ & $\begin{array}{l}290 \pm 9^{\& \triangleright \partial} \\
0.7 \pm 0.4^{\&}\end{array}$ & $\begin{array}{l}303 \pm 9^{8 x} \\
--\end{array}$ & $\begin{array}{l}307 \pm 8^{8} \\
0.7 \pm 0.2^{8}\end{array}$ & $\begin{array}{l}308 \pm 6^{8} \\
--\end{array}$ & $\begin{array}{l}309 \pm 9^{\& \partial} \\
0.7 \pm 0.4^{\&}\end{array}$ \\
\hline $\mathrm{DM}+\mathrm{AAM}+\mathrm{QT}$ & $\begin{array}{l}265-287 \\
1.4 \pm 0.5\end{array}$ & $\begin{array}{l}288 \pm 6^{8 \times} \\
--\end{array}$ & $\begin{array}{l}289 \pm 6^{8} \\
--\end{array}$ & $\begin{array}{l}290 \pm 7^{\& \partial} \\
0.9 \pm 0.2^{8 \mathrm{x}}\end{array}$ & $\begin{array}{l}290 \pm 8^{8} \\
--\end{array}$ & $\begin{array}{l}291 \pm 7^{\& \partial} \\
0.8 \pm 0.2^{\& \&}\end{array}$ & $\begin{array}{l}291 \pm 8^{8} \\
--\end{array}$ & $\begin{array}{l}292 \pm 6^{8 \partial} \\
0.8 \pm 0.1^{\&}\end{array}$ \\
\hline
\end{tabular}

* week 1 for acclimation; week 2-week 3 for STD induction; week 4-week 9: treated with ip Moriamin $1.6 \mathrm{~mL} /$ rat-day (AAM) or quercetin (QT) ip (70 mg/kg-day, suspended in PBS). $\dagger$ Data expressed in mean $\pm \mathrm{SD}(\mathrm{n}=8)$.

¥The symbol " $\&$ " in the same column indicate significant difference from the normal control $(p<0.05)$. The symbol " $\partial$ " in the same column indicates significant difference among the DM-related groups taking the DM rats as the reference.

Table 2. Characteristic physiological parameters associated with the Type 1 diabetes mellitus ${ }^{\star}, \dagger,+$.

\begin{tabular}{|c|c|c|c|c|c|c|c|c|}
\hline \multicolumn{9}{|c|}{ Group } \\
\hline \multirow{2}{*}{ Items/Normal range } & 1 & 2 & 3 & 4 & 5 & 6 & 7 & 8 \\
\hline & CTL & AAM & QT & $\mathrm{AAM}+\mathrm{QT}$ & DM & $\mathrm{DM}+\mathrm{AAM}$ & $\mathrm{DM}+\mathrm{QT}$ & $\mathrm{DM}+\mathrm{AAM}+\mathrm{QT}$ \\
\hline Insulin, $(\mu \mathrm{g} / \mathrm{L})(0.5-2.0)$ & $1.4 \pm 0.5$ & $1.3 \pm 0.4$ & $1.4 \pm 0.4$ & $1.4 \pm 0.3$ & $0.7 \pm 0.3^{\&}$ & $0.7 \pm 0.3^{\&}$ & $0.7 \pm 0.4^{\&}$ & $0.8 \pm 0.1^{\&}$ \\
\hline Blood sugar mg/dL & $185 \pm 15$ & $175 \pm 10$ & $160 \pm 5$ & $225 \pm 40$ & $320 \pm 45$ & $400 \pm 93$ & $421 \pm 80$ & $520 \pm 57$ \\
\hline Urine glucose (mg/dL) & 0.0 & 0.0 & 0.0 & 0.0 & $80 \pm 6^{8}$ & $52 \pm 7^{\& \partial}$ & $43 \pm 6^{\& \partial}$ & $45 \pm 5^{\& \partial}$ \\
\hline BW, g & $363 \pm 7$ & $362 \pm 6$ & $362 \pm 8$ & $350 \pm 8$ & $318 \pm 6^{8}$ & $292 \pm 5^{8}$ & $309 \pm 9^{8 x}$ & $292 \pm 6^{8 x}$ \\
\hline KW, g & $2.9 \pm 0.1$ & $2.9 \pm 0.1$ & $2.9 \pm 0.1$ & $2.8 \pm 0.1$ & $3.5 \pm 0.2^{8}$ & $3.5 \pm 0.2^{\&}$ & $3.4 \pm 0.2^{\&}$ & $3.8 \pm 0.2^{\&}$ \\
\hline KW/BW (\%) & $0.8 \pm 0.1$ & $0.8 \pm 0.4$ & $0.7 \pm 0.1^{\&}$ & $0.8 \pm 0.1$ & $1.1 \pm 0.3^{8}$ & $1.2 \pm 0.4^{\&}$ & $1.1 \pm 0.1^{\&}$ & $1.3 \pm 0.2^{\&}$ \\
\hline
\end{tabular}

${ }^{*}$ Measured on urine collected the first day after different treatments.

$\dagger$ Data expressed in mean \pm SD $(n=8)$.

†The symbol " $\&$ " in the same row indicate significant difference from the normal control $(p<0.05)$. The symbol " $\partial$ " in the same row indicates significant difference among the DM-related groups taking the DM rats as the reference. Dose: ip Moriamin $1.6 \mathrm{~mL} /$ rat-day. QT ip treated control (70 mg/kg-day, suspended in PBS).

$\mathrm{dL}, 175 \pm 10 \mathrm{mg} / \mathrm{dL}$, and $160 \pm 5 \mathrm{mg} / \mathrm{dL}$, respectively (Table 2). A slightly raised level $225 \pm 40 \mathrm{mg} / \mathrm{dL}$ was found for AA+QT control $(p<0.001)$ (Table 2). To compare, the blood glucose level in DM rats was raised to $320 \pm 45 \mathrm{mg} / \mathrm{dL}$. Further highly raised levels were seen in groups $\mathrm{DM}+\mathrm{AAM}, \mathrm{DM}+\mathrm{QT}$, and $\mathrm{DM}+\mathrm{AAM}+\mathrm{QT}$ to $400 \pm 93 \mathrm{mg} / \mathrm{dL}, 421 \pm 80 \mathrm{mg} / \mathrm{dL}$ and $520 \pm 57$ $\mathrm{mg} / \mathrm{dL}$, respectively $(p<0.01)$ (Table 2 ). Apparently, neither QT alone nor the cotherapy AMM+QT was effective to suppress the hyperglycemic state of T1DM (Table 2).

Conversely, the kidney weight (KW) in the DM associated rats were all increased due to inflammatory edema (Table 2). As seen, the kidney weight in the DM-related groups ranged within $3.5 \pm 0.2 \mathrm{~g}-3.8 \pm 0.2 \mathrm{~g}$ and the percent ratio KW/BW ranged within $1.1 \pm 0.3-1.3 \pm 0.2(p<0.05)$ (Table 2). The kidney weights of experimental control rats were rather comparable (i.e., $2.8 \pm 0.1 \mathrm{~g}-2.9 \pm 0.1 \mathrm{~g}$ ) and the percent $\mathrm{KW} / \mathrm{BW}$ ratio yielded a range within $0.7 \pm 0.1-0.8 \pm 0.4(p<0.05)$ (Table 2). As a consequence of compromization, the percent ratio $\mathrm{KW} /$ BW in DM groups was significantly raised (Table 2). QT alone suppressed the ratio to 0.7 , while in DM rats the ratio was 
slightly raised to 0.9 , underlying QT to be slightly effective for prevention of renal edema and inflammation (Table 2 ). The serum albumin levels in the four controls all fell into the normal range 3.8-5.4 g/dL (Table 3). T1DM rats exhibited severely lowered serum albumin level, $3.2 \pm 0.1 \mathrm{~g} / \mathrm{dL}(p<0.05)$ (Table 3). However, both QT and AAM+QT therapies seemed to be entirely ineffective and the final serum albumin levels still remained at $3.0 \pm 0.1 \mathrm{~g} / \mathrm{dL}$ and $3.3 \pm 0.1 \mathrm{~g} / \mathrm{dL}$, respectively $(p<0.05)$ (Table 3).

Substantially increased levels of the blood urea nitrogen (BUN) and the urinary urea nitrogen $\left(\mathrm{N}_{\mathrm{uu}}\right)$ associated with intensive serum albumin declination were perceived in all DM-associated groups. Healthy rats, when administered $\mathrm{AAM}$ alone or $\mathrm{AAM}+\mathrm{QT}$, yielded a slightly higher BUN than the normal and QT controls (Table 3). The T1DM rats revealed highest level of BUN, $30 \pm 5 \mathrm{mg} / \mathrm{dL}(p<0.05)$, and AAM, QT, or the cotherapy AAM+QT showed only slight suppressive effect (Table 3). Contrast to BUN, the $\mathrm{N}_{\mathrm{uu}}$ in all DM-related groups was more prominently elevated. The $\mathrm{N}_{\mathrm{uu}}$ levels were prominently elevated to $147 \pm 9 \mathrm{mg} / \mathrm{dL}$ and $158 \pm 8 \mathrm{mg} / \mathrm{dL}$ in T1DM and DM+AAM groups. Administration of QT or AAM+QT alleviated the $\mathrm{N}_{\text {uu }}$ level to $131 \pm 4 \mathrm{mg} / \mathrm{dL}$ and $121 \pm 6 \mathrm{mg} / \mathrm{dL}$, respectively $(p<0.05)$ (Table 3). Similar to $\mathrm{N}_{\mathrm{uu}}$ the urinary proteins were severely raised to $189 \pm 6 \mathrm{mg} / \mathrm{dL}$ in the T1DM rats (Table 3 ). AAM therapy further increased the level to $256 \pm 8 \mathrm{mg} / \mathrm{dL}$, QT and coadministration of $A A M<+Q T$ effectively suppressed the urinary protein levels to $137 \pm 8 \mathrm{mg} / \mathrm{dL}$ and $121 \pm 8 \mathrm{mg} / \mathrm{dL}$, respectively, yet still not completely recovered to the normal ranges $24 \pm 6 \mathrm{mg} / \mathrm{dL}, 88 \pm 5 \mathrm{mg} / \mathrm{dL}, 36 \pm 5 \mathrm{mg} / \mathrm{dL}$, and $78 \pm 7 \mathrm{mg} /$ $\mathrm{dL}$ respectively for the healthy control, $A A M, Q T$, and $A A M+Q T$ controls $(p<0.05)$ (Table 3 ).

The normal range of triglyceride (TG) for SD rats is 26-145 $\mathrm{mg} / \mathrm{dL}$ [23]. Level of TG in T1DM and AAM+DM did not show any significant difference from that of the healthy control $75 \pm 15 \mathrm{mg} / \mathrm{dL}$ (Table 3). Amazingly, QT raised the TG level of
DM to $255 \pm 45 \mathrm{mg} / \mathrm{dL}$, and further elevated to $553 \pm 75 \mathrm{mg} /$ $\mathrm{dL}$ after treated with AA+QT $(p<0.05)$ (Table 3 ).

Moreover, compared to the normal range $0.6 \pm 0.1 \mathrm{mg} /$ $\mathrm{dL}, 45 \pm 4 \mathrm{~mL} / 24 \mathrm{~h}, 1.88 \mathrm{~mL} / \mathrm{h}$ and $33 \pm 6 \mathrm{mg} / \mathrm{dL}$, the increase in serum creatinine $\left(\mathrm{Cr}_{\mathrm{sr}}\right)$, the $24 \mathrm{~h}$-urine volume $\left(\mathrm{V}_{\mathrm{ur}}\right)$, the urine flow rate $\left(\mathrm{U}_{\mathrm{h}}\right)$ and the urinary creatinine $\left(\mathrm{Cr}_{\mathrm{ur}}\right)$ levels were highly elevated in all DM-associated groups (Table 4). The serum creatinine levels were highly raised by T1DM, $\mathrm{DM}+\mathrm{AAM}, \mathrm{DM}+\mathrm{QT}$, and $\mathrm{DM}+\mathrm{AAM}+\mathrm{QT}$ respectively to $1.6 \pm 0.2$ $\mathrm{mg} / \mathrm{dL}, 1.8 \pm 0.2 \mathrm{mg} / \mathrm{dL}, 1.4 \pm 0.2 \mathrm{mg} / \mathrm{dL}$, and $1.5 \pm 0.2 \mathrm{mg} / \mathrm{dL}$ compared to $1.1 \pm 0.1 \mathrm{mg} / \mathrm{dL}, 0.7 \pm 0.1 \mathrm{mg} / \mathrm{dL}$, and $0.8 \pm 0.1 \mathrm{mg} /$ $\mathrm{dL}$ for AAM, QT and AAM+QT controls (Table 4). Accordingly, the creatinine clearance was substantially affected by T1DM, yielding respectively $11.0 \pm 0.6 \mathrm{~mL} / \mathrm{min}, 13.7 \pm 0.4 \mathrm{~mL} / \mathrm{min}$, $10.8 \pm 0.4 \mathrm{~mL} / \mathrm{min}$, and $8.6 \pm 0.3 \mathrm{~mL} / \mathrm{min}$ in $\mathrm{DM}, \mathrm{DM}+\mathrm{AAM}$, $\mathrm{DM}+\mathrm{QT}$, and $\mathrm{DM}+\mathrm{AAM}+\mathrm{QT}$ rats (Table 4), which were far excess in concentration when compared to $1.7 \pm 0.1 \mathrm{~mL} / \mathrm{min}, 3.8 \pm 0.1$ $\mathrm{mL} / \mathrm{m} 3.7 \pm 0.2 \mathrm{~mL} / \mathrm{min}$, and $7.0 \pm 0.3 \mathrm{~mL} / \mathrm{min}$ in the normal, AAM, QT, and AAM+QT control groups (Table 4).

On the other hand, GC/FID analysis for urinary amino acid excretion revealed the retention times were relatively long for all amino acids. The overall retention time covered a span from $13.291 \mathrm{~min}$ for alanine to $27.132 \mathrm{~min}$ for cysteine (Table 5).

More amazingly, the normal SD rats prominently showed serinuria (12.0 $\pm 0.2 \mathrm{mg} / \mathrm{mL}$ urine). When AAM was applied, the serine reabsorption was completely effected, instead the reabsorption of valine, arginine and histidine were suppressed (Table 6). QT alone severely inhibited the methionine reabsorption in the healthy rats, leading to extremely severe methioninuria up to $35.4 \pm 0.3 \mathrm{mg} / \mathrm{mL}(p<0.001)$ (Table 6). Although AAM+QT was able to completely alleviate the urinary loss of methionine, severe leucinuria $(11.3 \pm 0.2 \mathrm{mg} /$ $\mathrm{mL}$ ) and phenylalaninuria $(7.9 \pm 0.2 \mathrm{mg} / \mathrm{mL}$ ) occurred instead (Table 6). In T1DM rats severe glycinuria $(21.4 \pm 0.2 \mathrm{mg} / \mathrm{mL})$ and leucinuria $(6.6 \pm 0.2 \mathrm{mg} / \mathrm{mL})$ were apparently perceived.

Table 3. Serum and urinary biochemical parameters ${ }^{\star}, \dagger,+$.

\begin{tabular}{|c|c|c|c|c|c|c|c|c|}
\hline \multicolumn{9}{|c|}{ Group } \\
\hline \multirow{2}{*}{ Items/Normal range } & 1 & 2 & 3 & 4 & 5 & 6 & 7 & 8 \\
\hline & CTL & AAM & QT & $\mathbf{A A M}+\mathbf{Q T}$ & DM & $\mathrm{DM}+\mathrm{AAM}$ & $\mathrm{DM}+\mathrm{QT}$ & $\mathrm{DM}+\mathrm{AAM}+\mathrm{QT}$ \\
\hline $\begin{array}{l}\text { Serum } \mathrm{Ab}(\mathrm{g} / \mathrm{dL}) \\
(3.8-5.4)\end{array}$ & $4.5 \pm 0.2$ & $5.1 \pm 0.3^{8}$ & $4.4 \pm 0.1$ & $4.7 \pm 0.2$ & $3.2 \pm 0.1^{\&}$ & $3.8 \pm 0.1^{\& \partial}$ & $3.0 \pm 0.1^{\&}$ & $3.3 \pm 0.1^{\&}$ \\
\hline $\mathrm{TG} \mathrm{mg} / \mathrm{dL}$ & $75 \pm 15$ & $75 \pm 15$ & $81 \pm 5$ & $75 \pm 5$ & $120 \pm 20$ & $103 \pm 17$ & $255 \pm 45$ & $553 \pm 75$ \\
\hline BUN (mg/dL)(15-21) & $16 \pm 2$ & $20 \pm 3^{8}$ & $18 \pm 2$ & $22 \pm 3^{3 x}$ & $30 \pm 5^{8}$ & $28 \pm 3^{8 x}$ & $27 \pm 2^{8 x}$ & $29 \pm 4^{\&}$ \\
\hline $\begin{array}{l}\mathrm{N}_{\mathrm{UU}} \\
(\mathrm{mg} / \mathrm{dL})\end{array}$ & $55 \pm 6$ & $77 \pm 6^{8}$ & $60 \pm 8$ & $80 \pm 7^{\&}$ & $147 \pm 9^{\&}$ & $158 \pm 8^{\&}$ & $131 \pm 4^{\& \partial}$ & $121 \pm 6^{k \partial}$ \\
\hline $\mathrm{PT}_{\mathrm{ur}}(\mathrm{mg} / \mathrm{dL})(<100)$ & $24 \pm 6$ & $88 \pm 5^{8}$ & $36 \pm 5^{\&}$ & $78 \pm 7^{\&}$ & $189 \pm 6^{8}$ & $256 \pm 8^{\& \partial}$ & $137 \pm 8^{\& \partial}$ & $121 \pm 8^{8 \partial}$ \\
\hline
\end{tabular}

${ }^{\star}$ Measured on urine collected the first day after different treatments.

$\dagger$ Data expressed in mean \pm SD $(n=8)$.

¥The symbol " $\&$ " in the same row indicate significant difference from the normal control $(p<0.05)$. The symbol

" $\partial$ " in the same row indicates significant difference among the DM-related groups taking the DM rats as the reference.

Dose: ip Moriamin $1.6 \mathrm{~mL} /$ rat-day. QT ip treated control (70 mg/kg-day, suspended in PBS). 
Peng et al. Journal of Diabetes Research \& Clinical Metabolism 2014,

http://www.hoajonline.com/journals/pdf/2050-0866-3-5.pdf

Table 4. Parameters used to estimate the creatinine clearance ${ }^{\star}, \dagger$,.

\begin{tabular}{|c|c|c|c|c|c|c|c|c|}
\hline \multicolumn{9}{|c|}{ Group } \\
\hline Ito & 1 & 2 & 3 & 4 & 5 & 6 & 7 & 8 \\
\hline Items/Normal range & CTL & AAM & QT & $\mathbf{A A M}+\mathbf{Q T}$ & DM & $\mathbf{D M}+\mathbf{A A M}$ & $\mathrm{DM}+\mathrm{QT}$ & $\mathrm{DM}+\mathrm{AAM}+\mathrm{QT}$ \\
\hline $\mathrm{Cr}_{\mathrm{sr}}(\mathrm{mg} / \mathrm{dL})(0.2-0.8)$ & $0.6 \pm 0.1$ & $1.1 \pm 0.1^{\&}$ & $0.7 \pm 0.1$ & $0.8 \pm 0.1^{\&}$ & $1.6 \pm 0.2^{\&}$ & $1.8 \pm 0.2^{\& \partial}$ & $1.4 \pm 0.2^{8 \curvearrowright \partial}$ & $1.5 \pm 0.2^{8}$ \\
\hline $\mathrm{V}_{\mathrm{ur}}(\mathrm{mL} / 24 \mathrm{~h})$ & $45 \pm 4$ & $90 \pm 6^{\varsigma}$ & $54 \pm 7$ & $105 \pm 6^{\varsigma}$ & $197 \pm 7^{\&}$ & $171 \pm 8^{\& \partial}$ & $187 \pm 7^{8}$ & $180 \pm 9^{\& \partial}$ \\
\hline$v_{h}(\mathrm{~mL} / \mathrm{h})$ & 1.88 & 3.75 & 2.25 & 4.38 & 8.21 & 7.13 & 7.79 & 7.50 \\
\hline$v_{\min }, \times 10^{2}(\mathrm{~mL} / \mathrm{min})$ & 3.1 & 6.3 & 3.8 & 7.3 & 13.7 & 11.9 & 13.0 & 12.5 \\
\hline $\mathrm{Cr}_{\mathrm{ur}}(\mathrm{mg} / \mathrm{dL})$ & $33 \pm 6$ & $67 \pm 6^{8}$ & $68 \pm 7^{\&}$ & $77 \pm 8^{\&}$ & $128 \pm 7^{\&}$ & $131 \pm 5^{8}$ & $116 \pm 4^{\& \partial}$ & $103 \pm 3^{8 \partial}$ \\
\hline $\mathrm{C}_{\mathrm{Cr}}(\mathrm{mL} / \mathrm{min})$ & $1.7 \pm 0.1$ & $3.8 \pm 0.1^{\&}$ & $3.7 \pm 0.2^{\&}$ & $7.0 \pm 0.3^{8}$ & $11.0 \pm 0.6^{8}$ & $13.7 \pm 0.4^{\& \partial}$ & $10.8 \pm 0.4^{8 \partial}$ & $8.6 \pm 0.3^{\& \partial}$ \\
\hline
\end{tabular}

${ }^{*}$ Measured on urine collected the first day after different treatments.

$\dagger$ Data expressed in mean \pm SD $(n=8)$. The superscript symbol " $\&$ " in the same row indicate significant difference from the normal control $(p<0.05)$. The superscript symbol " $\partial$ " in the same row indicates significant difference among the DM-related groups taking the DM rats as the reference. Dose: ip Moriamin $1.6 \mathrm{~mL} /$ rat-day. QT ip treated control (70 $\mathrm{mg} / \mathrm{kg}$-day, suspended in PBS).

\$The creatinine clearance is calculated by the equation: $\mathrm{Ccr}=\left(\mathrm{Cr}_{\mathrm{ur}} \mathrm{Xv} v_{\min }\right) / \mathrm{Cr}_{\mathrm{pl}}$.

Table 5. Retention times of each individual amino acid in GC/FID analysis*.

\begin{tabular}{ll}
\hline Amino acid & Retention time (min) \\
\hline Alanine & 13.291 \\
Glycine & 13.496 \\
Valine & 14.629 \\
Leucine & 15.340 \\
Isoleucine & 15.554 \\
Norleucine (the internal standard) & 15.730 \\
Proline & 15.934 \\
Methionine & 17.835 \\
Serine & 18.123 \\
Threonine & $18.381-18.477$ \\
Phenylalanine & 19.007 \\
Aspartic acid & 19.627 \\
Hydroxy Proline & 19.816 \\
Glutamic acid & 20.566 \\
Asparagine & 21.042 \\
Lysine & 21.450 \\
Glutamine & 21.926 \\
Tryptophan & $21.983-22.113$ \\
Arginine & 22.255 \\
Histidine & 23.132 \\
Tyrosine & 23.535 \\
Cysteine & 27.132 \\
\hline Derivation of & \\
\hline
\end{tabular}

${ }^{*}$ Derivation of amino acids were conducted derived with the derivatization reagent MTBSTFA (N-Methyl-N-

(Tert-Butyldimethylsilyl)trifluoroacetamide in pyridine .

DM+AAM attenuated the glycine loss to $13.7 \pm 0.2 \mathrm{mg} / \mathrm{mL}$ with concomitantly increased urinary loss of isoleucine $(8.2 \pm 0.2$ $\mathrm{mg} / \mathrm{mL}$ ) (Table 6). To our astonishment, treating T1DM with QT elicited huge amount of methionine loss $(23.1 \pm 0.3 \mathrm{mg} / \mathrm{mL})$ (Table 6). However, in the meanwhile, we recognized that the combined therapy AAM+QT restored methionine reabsorption $(3.6 \pm 0.1 \mathrm{mg} / \mathrm{mL}$ in urine) at the expense of severe leucinuria $(11.3 \pm 0.4 \mathrm{mg} / \mathrm{mL}$ in urine) and isoleucinuria $(11.4 \pm 0.4 \mathrm{mg} /$ $\mathrm{mL}$ in urine) which were accompanied with moderate lysine and tryptophan loss (Table 6). Although the sum of amino acid excretion was very comparable among all groups, the total amino acid (TAA) loss was found to be extremely high, in particular in groups T1DM and DM+AAM+QT rats, showing losses of $8491 \mathrm{mg} /$ day and $8910 \mathrm{mg} /$ day (Table 6). Treatment with AAM alone and QT alone moderately suppressed the level to $6584 \mathrm{mg} / \mathrm{d}$ and $6545 \mathrm{mg} / \mathrm{d}$, respectively (Table 6).

\section{Discussion}

Consistent with Cooke and Plotnick [4], we showed the STZ induced DM rats revealed symptoms of hyperglycemia, insulin insufficiency, glucosuria and weight loss (Tables 1 and 2). In the meanwhile, the urinary glucose level was severely raised (Table 2), implicating the characteristic T1DM, a result similar to Cooke et al., [4].

Apparently, the body weight loss in the DM-associated rats was closely related with the serum insulin levels (Table1). Although QT is a potent prooxidant and acts as the insulin secretagogue [19], QT in this case failed to suppress the states of hyperglycemia (Figure 1) and hypertriglyceridemia (Table 3), underlying the typical T1DM resulting from the complete destruction of islets in pancreatic $b$ cells by STZ. Moreover, attention must be paid to the fact that both QT and AAM were unable to stimulate either insulin biosynthesis or secretion in the T1DM rats (Table 1), hence the DM+AAM and DM+AAM+QT rats showed the least weight gain (Table 1). Insulin helps cells in the liver, skeletal muscles, and fat tissue uptake glucose from blood. Action of insulin is mediated by tyrosine kinase 
Table 6. The absolute amount of amino acids appearing in the first day urine after different treatments ${ }^{\star}, \dagger,+$.

\begin{tabular}{|c|c|c|c|c|c|c|c|c|}
\hline \multirow{3}{*}{ AA } & \multicolumn{7}{|c|}{${ }^{\dagger}$ Group No. /mg amino acid / $\mathrm{mL}$ urine } & \multirow{3}{*}{$\begin{array}{l}8 \\
\mathrm{DM}+\mathrm{AAM}+\mathrm{QT}\end{array}$} \\
\hline & 1 & 2 & 3 & 4 & 5 & 6 & 7 & \\
\hline & Control & AAM & QT & $\mathrm{AAM}+\mathrm{QT}$ & DM & $\mathrm{DM}+\mathrm{AAM}$ & $\mathrm{DM}+\mathrm{QT}$ & \\
\hline Gly & $1.4 \pm 0.1$ & $4.1 \pm 0.1^{\&}$ & $0.2 \pm 0.1^{\&}$ & $4.6 \pm 0.2^{\&}$ & $21.4 \pm 0.2^{\& \&}$ & $13.7 \pm 0.2^{\& \& d}$ & $3.9 \pm 0.2^{\& \partial}$ & $4.2 \pm 0.1^{\& \partial}$ \\
\hline Val & $0.7 \pm 0.1$ & $3.6 \pm 0.2^{\&}$ & $0.2 \pm 0.1^{\&}$ & ND & $2.6 \pm 0.1^{8}$ & $2.5 \pm 0.2^{\&}$ & $2.7 \pm 0.1^{\&}$ & $3.1 \pm 0.2^{\& \partial}$ \\
\hline Leu & $4.4 \pm 0.2$ & $6.0 \pm 0.2^{\&}$ & $0.3 \pm 0.0^{\&}$ & $11.3 \pm 0.2^{\&}$ & $6.6 \pm 0.2^{\&}$ & $6.2 \pm 0.2^{\&}$ & $2.7 \pm 0.1^{\& \partial}$ & $11.3 \pm 0.4^{\& \partial}$ \\
\hline Ile & $0.7 \pm 0.1$ & ND & $0.3 \pm 0.0^{*}$ & $1.2 \pm 0.3^{8}$ & $0.5 \pm 0.1^{8 x}$ & $8.2 \pm 0.2^{8 \partial \partial}$ & $1.3 \pm 0.0^{8 \partial \partial}$ & $11.4 \pm 0.4^{\& \partial}$ \\
\hline Ser & $12.0 \pm 0.2$ & ND & ND & ND & ND & ND & ND & ND \\
\hline Phe & $3.9 \pm 0.1$ & $2.4 \pm 0.1^{\&}$ & $0.2 \pm 0.0^{\&}$ & $7.9 \pm 0.2^{\&}$ & $2.0 \pm 0.1^{\&}$ & $1.5 \pm 0.1^{\&}$ & $1.7 \pm 0.1^{\& \#}$ & $2.9 \pm 0.1^{\& \partial \partial}$ \\
\hline Met & $6.2 \pm 0.2$ & $3.9 \pm 0.1^{8}$ & $35.4 \pm 0.3^{8 \& \& 8}$ & $2.5 \pm 0.2^{\&}$ & $5.9 \pm 0.1$ & $2.1 \pm 0.1^{8}$ & $23.1 \pm 0.3^{8 \& 8}$ & $3.6 \pm 0.1^{\& \partial}$ \\
\hline $\operatorname{Trp}$ & $1.2 \pm 0.2$ & $1.7 \pm 0.1^{\& 8}$ & $0.1 \pm 0.0^{8 \& 8}$ & $1.8 \pm 0.1^{\&}$ & $2.1 \pm 0.1^{\&}$ & $1.7 \pm 0.1^{\&}$ & $0.2 \pm 0.1^{\& \partial}$ & $3.4 \pm 0.1^{8 \partial \partial}$ \\
\hline Arg & $0.6 \pm 0.2$ & $6.9 \pm 0.2^{\&}$ & $0.1 \pm 0.0^{\&}$ & $2.4 \pm 0.0^{\&}$ & ND & $0.8 \pm 0.1$ & $0.1 \pm 0.0^{\& \partial}$ & $1.9 \pm 0.1^{\& \partial \partial}$ \\
\hline Lys & $3.3 \pm 0.1$ & $1.0 \pm 0.0^{\&}$ & $0.3 \pm 0.1^{\&}$ & $4.4 \pm 0.1^{\&}$ & $2.9 \pm 4^{8}$ & $1.2 \pm 0.1^{8 \partial \partial}$ & $0.3 \pm 0.0^{\& \partial}$ & $5.8 \pm 0.2^{8 \partial \partial}$ \\
\hline His & $0.7 \pm 0.1$ & $6.5 \pm 0.1^{\&}$ & ND & $\mathrm{ND}$ & ND & $0.6 \pm 0.1$ & $0.1 \pm 0.0^{\&}$ & $1.9 \pm 0.0^{8}$ \\
\hline Sum & 35.1 & 36.1 & 37.1 & 36.1 & 43.1 & 38.5 & 35.0 & 49.5 \\
\hline TAA $(\mathrm{mg} / \mathrm{d})$ & 1580 & 3249 & 2003 & 3791 & 8491 & 6584 & 6545 & 8910 \\
\hline
\end{tabular}

${ }^{*}$ Measured on urine collected the first day after different treatments.

$\dagger$ Data expressed in mean \pm SD $(n=8)$. The superscript symbol " $\&$ " in the same row indicate significant difference from the normal control. " $\&$ " for $p<0.05$; " $\& \&$ " for $p<0.01$; " $\& \& \&$ " for $p<0.001$. The superscript symbol " $\partial$ " in the same row indicates significant difference among the DM-related groups taking the DM rats as the reference $(p<0.05)$. Dose: ip Moriamin $1.6 \mathrm{~mL} /$ rat-day. QT ip treated control $(70 \mathrm{mg} / \mathrm{kg}$-day, suspended in PBS).

$\ddagger$ Sum: sum of amino acid in per $\mathrm{mL}(\mathrm{mg} / \mathrm{mL})$.

TAA: total amino acid excreted per day $(\mathrm{mg} / 24 \mathrm{~h})$

ND: not detected

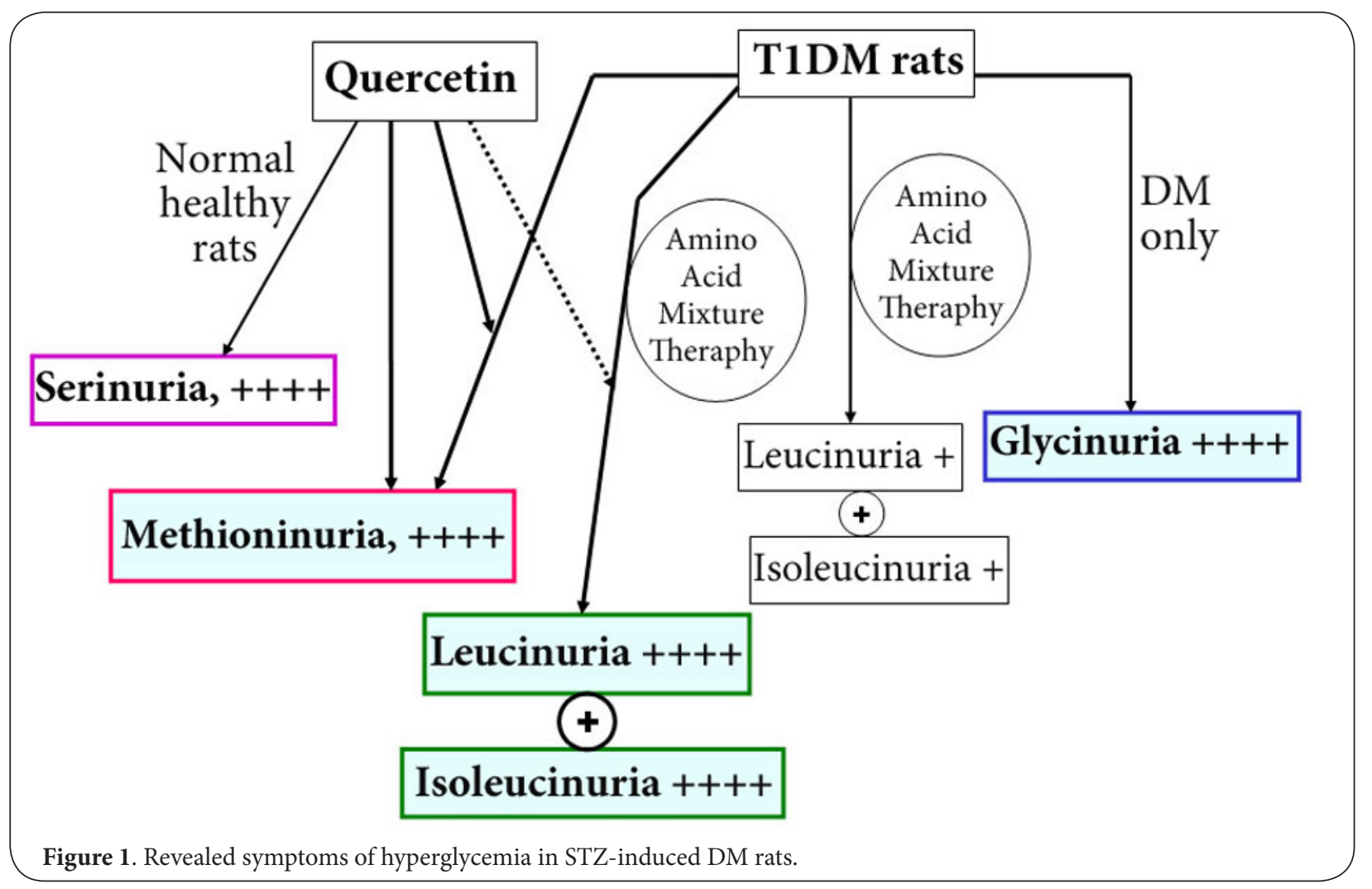


Peng et al. Journal of Diabetes Research \& Clinical Metabolism 2014, http://www.hoajonline.com/journals/pdf/2050-0866-3-5.pdf

enzyme, which is part of the insulin receptor, and the tyrosine kinase triggers a phosphorylation cascade in the cytoplasm to influence intracellular processes [8]. Without the insulin biosynthesis, QT totally failed to affect the blood glucose level, a phenomenon entirely different from that for type 2 DM [19].

Taken together, the severe body weight loss was ascribed to insulin insufficiency (Tables 1 and 2), declined serum albumin level (Table 3) [9], increased urinary albumin excretion (albuminuria) [9], proteinuria (Table 3), elevated BUN (Table 3), increased creatinine clearance (Table 4), and amino acid loss due to failure of reabsorption (Table 6). In addition, the urinary amino acid profile might give certain degree of information about the body weight loss. In the DM-associated groups, more apparent loss of essential amino acids was perceived, like loss of leucine and methionine in the T1DM rats; loss of leucine and isoleucine in DM+AAM rats, the methionine loss in the $\mathrm{DM}+\mathrm{QT}$ rats, and loss of leucine, isoleucine and lysine in the $\mathrm{DM}+\mathrm{AAM}+\mathrm{QT}$ group (Table 6). Protein helps maintain muscle mass, is used for enzymes involved in liver detoxification, and is required for immune function. Albuminuria and reduced GFR have been demonstrated to be risk factors for progressive kidney failure and cardiovascular disease [24]. The increase of $\mathrm{KW} / \mathrm{BW}$ ratio in reality was a compromised consequence, i.e., the severely reduced body weight and the enlarged kidney due to renal edema and inflammation [4].

Literature indicated that amino acid infusions can increase the renal blood flow (RBF), glomerular filtration rate (GFR) and stimulate tubular reabsorption in adults [25], the plasma amino acid levels accordingly can be increased up to 20fold $(p<0.005)$ with GFR increased by $50 \pm 8 \%(p<0.001)$ [24]. Under such circumstance, the reabsorption threshold could be easily exceeded.

On the other hand, QT inhibited the renal catechol O-methyltransferase, only O-methylated estradiols could be normally excreted into urine $[19,25,26]$, suggesting the possibility that quercetin may injure kidney by inhibiting the methylation of certain estrogenic nucleus.

In renal, the colocalization of exclusive reabsorption and metabolism of amino acids makes the pars recta the tubule site for the recycling of the carbon structure of $\mathrm{D}$-amino acids [27]. Nonetheless, the great excess of serinuria $(12.0 \pm 0.2$ $\mathrm{mg} / \mathrm{mL}$ ) by normal SD rats (Table 6) was really astonishing. The reason is still unclear. AAM supplementary therapy completely abolished the serinuria (Table 6). Conversely, in DM rats serinuria was entirely undetected. Instead, glycinuria predominated (Table 6), implicating QT being able to play the role in remodeling the amino acid (or protein) metabolism. Biochemically the rates of homocysteine remethylation and serine synthesis were inversely correlated $(r=-0.89, p<0.001)$ [28], suggesting the recovered serine reabsorption (Table 6) could decrease the demand for homocysteine remethylation.

In addition, biochemical and clinical vitamin $\mathrm{B}_{12}$ deficiency have been demonstrated to be highly prevalent among patients with T1DM and T2DM $[29,30]$. $B_{12}$-deficiency could elicit impaired conversion of 5-MTHF to THF, which in turn inhibits the methionine biosynthesis from homocysteine $[29,30]$ (see Supplement Figure S1). Alternatively, serine is required for conversion of THF into 5,10-methylene-THF that acts a methyl donor for conversion of dUMP into dTMP (See Supplement Figure S1). Wagner et al., had demonstrated the complex interactions between the different subunits of heterodimeric amino acid transporters [31]. Whether quercetin could remodel these different subunits remains to further investigation.

Furthermore, contrary to Vannini et al., [18], we found severe glycinuria instead of alaninuria in both $D M$ and $D M+A A M$ rats (Table 6). Either QT or AAM+QT alleviated such abnormal excretion (Table 6).

Based on functional studies in kidney and intestine and the amino acid profile in the urine of individuals with different aminoacidurias, five transport activities have been proposed, the "neutral system" or "methionine preferring system" is the one that transports all neutral amino acids [32]. The mechanistic cause in impairing renal methionine reabsorption is still unclear. Presumably methionine, leucine and isoleucine compete at this transporter. While in treating rats with DM+AAM+QT, it seemed such an inhibition apparently was shifted to transporters of leucine, isoleucine, valine, tryptophan, arginine, lysine, and histidine (Table 6).

Impaired arginine transport contributes to low renal NO bioavailability and may evoke renal type hypertension [33]. Tryptophan glycoconjugate, 2-(a-mannopyranosyl)-Itryptophan (MPT), has been shown to be a novel marker of renal function [34]. Lysine has been considered to be a major constituent of amino acid parenteral nutrition solutions which was shown to increase the severity of various types of acute renal failure in the rat [35]. High-dose lysine alone is capable of causing acute renal failure [35]. Recent literature revealed the action mechanism to be due to the formation of carboxymethyllysine (CML), an advanced glycation end product (AGE). We showed T1DM also exhibited hypertriglyceridemia (Table 3). Hypereglycemia and hyperlipidemia can trigger AGE-production [19]. AGEs are associated with impaired renal function in diabetes and in uremia [36]. Plasma CML is independently associated with chronic kidney disease (CKD) and is an independent predictor of decline in renal function in older community-dwelling adults [36]. In pregnant women, expression of histidine decarboxylase is upregulated in superficial cortical nephrons [37]. The amino acid L-arginine has been shown to be a reducer of cross-linking in aging collage type IV and is strongly associated with a reduction of collagen accumulation of $\mathrm{N}$-epsilon-(carboxymethyl)lysine (an AGE) [38] in aging mice and in diabetic mice [36], enhancing glomerular filtration rate [39], decresed the formation of AGE-proteins in the vascular mesenteric bed and in the lens of Golden Syrian hamsters stimulated by hyperlipidemia and hyperglycemia [40]. The plasma methionine, leucine, and isoleucine levels of normal SD rats are $60.1 \pm 7.4 \mu \mathrm{mol} / \mathrm{L}(11.50$ 
$\mathrm{mg} / \mathrm{mL}), 173.9 \pm 23.2 \mu \mathrm{mol} / \mathrm{L}(7.54 \mathrm{mg} / \mathrm{mL})$, and $99.2 \pm 12.3$ $\mu \mathrm{mol} / \mathrm{L}(13.01 \mathrm{mg} / \mathrm{mL}$ ) respectively (Table 7$)$. We found huge amount of methionine excreted into urine by groups QT and DM+QT (Table 6), underlying the inherent inhibitory effect of QT on the renal methionine transporter. Methionine loss may impair DNA methylation, resulting in birth defects, muscle

Table 7. Comparison of the plasma amino acid levels between normal human and Sprague Dawley rats.

\begin{tabular}{l|ll}
\hline \multirow{2}{*}{ Amino acid } & \multicolumn{2}{l}{ Plasma level $(\boldsymbol{\mu m o l} / \mathrm{L})$} \\
\cline { 2 - 3 } & Human $^{*}$ & SD rats $^{\dagger}$ \\
\hline Glycine & -- & -- \\
Childre & $110-240$ & $230.4 \pm 19.5$ \\
Adults & $170-330$ & -- \\
Serine & -- & -- \\
Children & $93-150$ & $169.3 \pm 8.0$ \\
Adults & $56-140$ & -- \\
Valine & -- & -- \\
Children & $160-350$ & $205.3 \pm 25.4$ \\
Adults & $150-310$ & -- \\
Isoleucine & -- & -- \\
Children & $37-140$ & $99.2 \pm 12.3$ \\
Adults & $42-100$ & -- \\
Leucine & -- & -- \\
Children & $70-170$ & $173.9 \pm 23.2$ \\
Adults & $66-170$ & -- \\
Methionine & -- & -- \\
Children & $13-30$ & $60.1 \pm 7.4$ \\
Adults & $16-30$ & -- \\
Lysine & -- & $403.4 \pm 95.9$ \\
Children & $120-290$ & -- \\
Adults & $150-220$ & -- \\
\hline & & \\
\hline
\end{tabular}

${ }^{\star}$ Human data are depicted from Health Encyclopedia. $\dagger$ Muratsubaki and Yamaki (2011).

weakness as well as body weight loss [19].

Pathologically, the distribution profile among the plasma amino acid concentrations varies with the stage of T1DM [41] and the plasma concentrations of valine, leucine, isoleucine, as well as the total branched chain amino acids, alanine, citrulline and proline in T1DM are significantly higher than the normal [42]. Failure in intestinal uptake and renal reabsorption of amino acids can elicit protein malnutrition-related diabetes mellitus [42].

\section{Conclusions}

Taken together, the severe body weight loss and reduced KW/ BW ratio can be ascribed to insulin insufficiency, declined serum albumin level, increased albuminuria, proteinuria, elevated BUN, increased creatinine clearance, and amino acid loss due to failure of reabsorption and the urinary amino acid profile. Normal rats exhibits serinuria and methioninuria. AAM therapy decreases the glycine excretion, instead evokes isoleucinuria. QT alone therapy can provoke severe methioninuria in both the healthy and DM+QT groups.
AAM + QT can rescue methioninuria of T1DM at the expense of leucinuria, isoleucinuria and reabsorption failure for tryptophan, arginine and lysine, implicating the use of AAM with extra supplement of insulin, leucne, isoleucine, tryptophan, arginine and lysine is feasible for alleviation of T1DM.

\section{Additional files

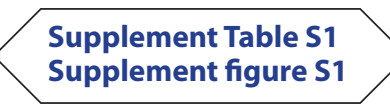

List of abbreviations

AAM: Amino acid mixture treated with Moriamin $1.6 \mathrm{~mL} /$ rat-day. eGFR: Estimated glomerular filtration rate

BW: Body weight

$\mathrm{KW}$ : Kidney weight

CCr: Creatinine clearance

NUU: Urinary urea nitrogen

CNS: Central nervous system

PTur: Urinary protein level

Crpl: Plasma creatinine level

QT: Quercetin

Crur: Urinary creatinine level

STZ: Streptozotocin

CTL: Control

T1DM: Type 1 diabetes mellitus

CV: Cardiovascular Vur 24 h-urine volume

DM: Diabetes mellitus

Competing interests

The authors declare that they have no competing interests.

\section{Authors' contributions}

\begin{tabular}{|l|c|c|c|c|c|c|}
\hline Authors' contributions & CP & YK & CH & CKH & KC & RYP \\
\hline Research concept and design & $\checkmark$ & -- & -- & - & $\checkmark$ & - \\
\hline Collection and/or assembly of data & -- & $\checkmark$ & $\checkmark$ & -- & -- & -- \\
\hline Data analysis and interpretation & $\checkmark$ & $\checkmark$ & -- & -- & $\checkmark$ & $\checkmark$ \\
\hline Writing the article & $\checkmark$ & -- & -- & -- & $\checkmark$ & $\checkmark$ \\
\hline Critical revision of the article & -- & -- & -- & -- & $\checkmark$ & $\checkmark$ \\
\hline Final approval of article & $\checkmark$ & -- & -- & -- & -- & -- \\
\hline Statistical analysis & -- & -- & -- & $\checkmark$ & -- & -- \\
\hline
\end{tabular}

\section{Acknowledgement}

This work was supported by the funding of National Science Council NSC 102-2313-B-018-001-MY3; NSC 102-2320-B-038-025; and the Chi Mei Medical Center-Taipei Medical University 103CMTMU-06. We also thank the partial financial support of National Science Council NSC 102-2622-B-241-002-CC3 in joint project with San-Jin Starch Industrials Co.

\section{Publication history}

Editor: Jon S. Odorico, University of Wisconsin-Madison, USA. EIC: Geoffrey Burnstock, University College London, UK.

Received: 02-Dec-2013 Final Revised: 01-Feb-2014

Accepted: 02-Apr-2014 Published: 16-Apr-2014

\section{References}

1. Barnes AS. The epidemic of obesity and diabetes: trends and treatments. Tex Heart Inst J. 2011; 38:142-4. | PubMed Abstract | PubMed Full Text 
2. Garg SK. Rising epidemic of diabetes and hypertension in Asia. Diabetes Technol Ther. 2012; 14:1-2. | Article | PubMed

3. NIH (National Institute of Health): 2013. Fact Sheet.

4. Cooke DW and Plotnick L. Type 1 diabetes mellitus in pediatrics. Pediatr Rev. 2008; 29:374-84. | Article | PubMed

5. Bruno Vergès. Lipid Disorders in Type 1 Diabetes Type 1 DiabetesComplications, Pathogenesis, and Alternative Treatments. Prof. Chih-Pin Liu (Ed.), 2011. | Article

6. Harries AD, Lin Y, Satyanarayana S, Lonnroth K, Li L, Wilson N, Chauhan LS, Zachariah R, Baker MA, Jeon CY, Murray MB, Maher D, Bygbjerg IC, Enarson DA, Billo NE and Kapur A. The looming epidemic of diabetesassociated tuberculosis: learning lessons from HIV-associated tuberculosis. Int J Tuberc Lung Dis. 2011; 15:1436-44. | Article | PubMed

7. Leeds JS, Hopper AD, Hadjivassiliou M, Tesfaye S and Sanders DS. High prevalence of microvascular complications in adults with type 1 diabetes and newly diagnosed celiac disease. Diabetes Care. 2011; 34:2158-63. | Article | PubMed Abstract | PubMed Full Text

8. Mohan V, Radhika G, Vijayalakshmi P and Sudha V. Can the diabetes/ cardiovascular disease epidemic in India be explained, at least in part, by excess refined grain (rice) intake? Indian J Med Res. 2010; 131:36972. | Pdf | PubMed

9. Nakamoto $\mathrm{H}$ and Suzuki $\mathrm{H}$. Hypoproteinemia in patients with diabetes undergoing continuous ambulatory peritoneal dialysis is attributable to high permeability of peritoneal membrane. Perit Dial Int. 2003; 23 Suppl 2:S72-8. | Article | PubMed

10. Palacin M, Bertran J, Chillaron J, Estevez R and Zorzano A. Lysinuric protein intolerance: mechanisms of pathophysiology. Mol Genet Metab. 2004; 81 Suppl 1:S27-37. | Article | PubMed

11. Broer $\mathrm{S}$. Amino acid transport across mammalian intestinal and renal epithelia. Physiol Rev. 2008; 88:249-86. | Article | PubMed

12. Silbernagl $\mathrm{S}$. The renal handling of amino acids and oligopeptides. Physiol Rev. 1988; 68:911-1007. | Article | PubMed

13. Camargo SM, Bockenhauer D and Kleta R. Aminoacidurias: Clinical and molecular aspects. Kidney Int. 2008; 73:918-25. | Article | PubMed

14. Verrey F, Ristic Z, Romeo E, Ramadan T, Makrides V, Dave MH, Wagner CA and Camargo SM. Novel renal amino acid transporters. Annu Rev Physiol. 2005; 67:557-72. | Article | PubMed

15. Kleta R and Gahl WA. Collecting evidence: the case of collectrin (Tmem27) and amino acid transport. Am J Physiol Renal Physiol. 2007; 292:F531-2. | Article | PubMed

16. Vester $U$, Schubert M, Offner $G$ and Brodehl J. Distal myopathy in nephropathic cystinosis. Pediatr Nephrol. 2000; 14:36-8. | Article | PubMed

17. Bailey CG, Ryan RM, Thoeng AD, Ng C, King K, Vanslambrouck JM, AurayBlais C, Vandenberg RJ, Broer S and Rasko JE. Loss-of-function mutations in the glutamate transporter SLC1A1 cause human dicarboxylic aminoaciduria. J Clin Invest. 2011; 121:446-53. | Article | PubMed Abstract I PubMed Full Text

18. Vannini P, Marchesini G, Forlani G, Angiolini A, Ciavarella A, Zoli M and Pisi E. Branched-chain amino acids and alanine as indices of the metabolic control in type 1 (insulin-dependent) and type 2 (non-insulindependent) diabetic patients. Diabetologia. 1982; 22:217-9. | Article | PubMed

19. Hsieh CL, Peng CC, Cheng YM, Lin LY, Ker YB, Chang CH, Chen KC and Peng RY. Quercetin and ferulic acid aggravate renal carcinoma in longterm diabetic victims. J Agric Food Chem. 2010; 58:9273-80. | Article | PubMed

20. Stevens LA, Coresh J, Greene T and Levey AS. Assessing kidney function-measured and estimated glomerular filtration rate. N Engl J Med. 2006; 354:2473-83. | Article | PubMed

21. Deng $C$, Deng $Y$, Wang B and Yang X. Gas chromatography-mass spectrometry method for determination of phenylalanine and tyrosine in neonatal blood spots. J Chromatogr B Analyt Technol Biomed Life Sci. 2002; 780:407-13. | Article | PubMed

22. Ninomiya T, Perkovic V, de Galan BE, Zoungas $S$, Pillai $A$, Jardine $M$, Patel A, Cass A, Neal B, Poulter N, Mogensen CE, Cooper M, Marre M, Williams
B, Hamet P, Mancia G, Woodward M, Macmahon S and Chalmers J. Albuminuria and kidney function independently predict cardiovascular and renal outcomes in diabetes. J Am Soc Nephrol. 2009; 20:1813-21. I Article | PubMed Abstract | PubMed Full Text

23. Peng CC, Hsieh CL, Ker YB, Wang HY, Chen KC and Peng RY. Selected nutraceutic screening by therapeutic effects on doxorubicin-induced chronic kidney disease. Mol Nutr Food Res. 2012; 56:1541-58. | Article I PubMed

24. Marsh AC, Lumbers ER and Gibson KJ. Renal, cardiovascular and endocrine responses of fetal sheep at $\mathbf{0 . 8}$ of gestation to an infusion of amino acids. J Physiol. 2002; 540:717-28. | Article | PubMed Abstract | PubMed Full Text

25. Zhu BT and Liehr JG. Quercetin increases the severity of estradiolinduced tumorigenesis in hamster kidney. Toxicol Appl Pharmacol. 1994; 125:149-58. | Article | PubMed

26. Zhu BT and Liehr JG. Inhibition of catechol O-methyltransferasecatalyzed 0-methylation of 2- and 4-hydroxyestradiol by quercetin. Possible role in estradiol-induced tumorigenesis. J Biol Chem. 1996; 271:1357-63. | Article | PubMed

27. Silbernagl S, Volker $K$ and Dantzler WH. D-Serine is reabsorbed in rat renal pars recta. Am J Physiol. 1999; 276:F857-63. I Article I PubMed

28. Cuskelly GJ, Stacpoole PW, Williamson J, Baumgartner TG and Gregory $\mathrm{JF}, 3$ rd. Deficiencies of folate and vitamin $B(6)$ exert distinct effects on homocysteine, serine, and methionine kinetics. Am J Physiol Endocrinol Metab. 2001; 281:E1182-90. | Article I PubMed

29. Kibirige $D$ and Mwebaze R. Vitamin B12 deficiency among patients with diabetes mellitus: is routine screening and supplementation justified? J Diabetes Metab Disord. 2013; 12:17. | Article | PubMed Abstract | PubMed Full Text

30. Birn $\mathrm{H}$. The kidney in vitamin B12 and folate homeostasis: characterization of receptors for tubular uptake of vitamins and carrier proteins. Am J Physiol Renal Physiol. 2006; 291:F22-36. | Article | PubMed

31. Wagner CA, Lang $F$ and Broer S. Function and structure of heterodimeric amino acid transporters. Am J Physiol Cell Physiol. 2001; 281:C1077-93. | Article | PubMed

32. World Health Organization. Diabetes mellitus. Tech Rep Ser. 1985. 727:20-4.

33. Rajapakse NW, Kuruppu S, Hanchapola I, Venardos K, Mattson DL, Smith $\mathrm{Al}$, Kaye DM and Evans RG. Evidence that renal arginine transport is impaired in spontaneously hypertensive rats. Am J Physiol Renal Physiol. 2012; 302:F1554-62. | Article | PubMed

34. Takahira R, Yonemura K, Yonekawa O, Iwahara K, Kanno T, Fujise $Y$ and Hishida A. Tryptophan glycoconjugate as a novel marker of renal function. Am J Med. 2001; 110:192-7. | Article I PubMed

35. Racusen LC, Whelton A and Solez K. Effects of lysine and other amino acids on kidney structure and function in the rat. Am J Pathol. 1985; 120:436-42. | PubMed Abstract | PubMed Full Text

36. Semba RD, Fink JC, Sun K, Bandinelli S, Guralnik JM and Ferrucci L. Carboxymethyl-lysine, an advanced glycation end product, and decline of renal function in older community-dwelling adults. Eur J Nutr. 2009; 48:38-44. | Article | PubMed Abstract | PubMed Full Text

37. Morgan TK, Montgomery K, Mason V, West RB, Wang L, van de Rijn M and Higgins JP. Upregulation of histidine decarboxylase expression in superficial cortical nephrons during pregnancy in mice and women. Kidney Int. 2006; 70:306-14. | Article I PubMed

38. Radner W, Hoger H, Lubec B, Salzer H and Lubec G. L-arginine reduces kidney collagen accumulation and $\mathrm{N}$-epsilon-(carboxymethyl)lysine in the aging NMRI-mouse. J Gerontol. 1994; 49:M44-6. | Article | PubMed

39. Reckelhoff JF, Kellum JA, Jr., Racusen LC and Hildebrandt DA. Long-term dietary supplementation with L-arginine prevents age-related reduction in renal function. Am J Physiol. 1997; 272:R1768-74. | Article | PubMed

40. Georgescu A and Popov D. Age-dependent accumulation of advanced glycation endproducts is accelerated in combined hyperlipidemia and hyperglycemia, a process attenuated by L-arginine. J Am Aging Assoc. 2000; 23:33-40. | Article | PubMed Abstract | PubMed Full Text 
Peng et al. Journal of Diabetes Research \& Clinical Metabolism 2014, http://www.hoajonline.com/journals/pdf/2050-0866-3-5.pdf

41. Mochida T, Tanaka T, Shiraki Y, Tajiri H, Matsumoto S, Shimbo K, Ando T, Nakamura K, Okamoto M and Endo F. Time-dependent changes in the plasma amino acid concentration in diabetes mellitus. Mol Genet Metab. 2011; 103:406-9. | Article | PubMed

42. Abdulkadir J. Malnutrition-related diabetes mellitus in Africa. Int J Diab Dev Countries. 1993; 13:22-8. I Pdf

\section{Citation:}

Peng C-C, Ker Y-B, Hsieh C-L, Huang C-N, Chen $\mathrm{K}-\mathrm{C}$ and Peng RY. Therapeutic effect of amino acid mixture on type 1 diabetes mellitus with impaired renal methionine reabsorption. J Diab Res Clin Met. 2014; 3:5.

http://dx.doi.org/10.7243/2050-0866-3-5 